<短 報 $>$

\title{
腫瘤血洞から直接類洞に流出する血行路とコロナ様濃染の 出現についての考察
}

\begin{tabular}{|c|c|c|c|c|c|c|}
\hline 竜一1)* & 西島 & 規浩 ${ }^{1)}$ & 中辻 正人 ${ }^{1)}$ & 川上 & 尚人 ${ }^{1)}$ & 坂本 \\
\hline 裕央 ${ }^{11}$ & 斎藤 & 澄夫 ${ }^{1)}$ & 波多野貴昭1) & 池田 & 敦之社 & 那須 \\
\hline 浩樹1) & 木村 & 達 ${ }^{1)}$ & 往夫 ${ }^{1)}$ & 中島 & 收 ${ }^{2)}$ & \\
\hline
\end{tabular}

緒言 : CT during hepatic arteriography (CTHA) お よび CT during arterioportography (CTAP) は, 肝腫 瘤の血行動態を最も詳細に調べうる modality であり, single level dynamic CTHA (sCTHA) 撮像後期のリン グ様の濃染（コロナ様濃染）は, 肝細胞癌, 多血性転 移性肝癌，および多血性過形成結節において認められ $3^{1) ~ 3)}$. これは肝腫瘤からの流出血流が, 周辺の肝実質 を還流するために生じる現象であるが，今回我々は， Focal nodular hyperplasia (FNH) においてもコロナ様 濃染を呈した症例を経験した。 小門脈枝以外の流出血 流路を介するコロナ様濃染出現のメカニズムについて 考察したので報告する.

症例 $1: 28$ 歳, 男性. 肝に $7 \mathrm{~cm}$ 大の結節性病変を認 めた．腹部 US, CT, 血管造影にて車軸様血管の描出 を認め, CTAPにて低吸収を, CTHAにて高吸収を呈 した. s CTHA では, 結節の中心から強い濃染がはじま り, 結節全体に及び, 内部から washoutされるととも にコロナ様濃染を呈した(Fig. 1-a, b, c). 生検にて採取 された組織は, 瘏痕様組織を認め, 小型の筋性血管と 細胆管の増生, 炎症細胞浸潤, 小型偽腺管様構造が散 見される過形成性の肝細胞の集簇がみられた. 中心性 線維性痏痕や車軸様血管の描出とあわせ, FNH と診断 した (Fig. 1-d).

症例 2 : (日本消化器病学会雑誌, 印刷中) 73 歳, 女 性. 結節内結節型肝細胞癌を指摘された. CTAPでは, $2 \mathrm{~cm}$ 大の結節は低吸収を呈し, 内包される $1 \mathrm{~cm}$ 大の結 節はさらに低吸収を呈した。 CTHA では，前者は低吸 収を呈し, 後者は高吸収を呈した. s CTHAにて, 内包

1）大阪赤十字病院消化器科

2) 久留米大学医学部病理学教室

*Corresponding author: rkita@osaka-med.jrc.or.jp $<$ 受付日2007年1月5日 $><$ 採択日2007年3月30日 $>$
される結節の外周にコロナ様濃染を認めた（Fig. 2-a, b, c). 生検にて採取された組織より, 腫瘍外周を占める 結節は不規則な索状配列と細胞密度の軽度上昇を認め Edmondson I 相当の高分化肝細胞癌と診断され, 内包 される結節は細胞密度の上昇と染色性の増強, 2-3 層の 明瞭な細索状配列を呈する Edmondson I II 相当の高〜 中分化肝細胞癌と診断されたが, その境界には被膜を 有さず，置換型浸潤を観察した（Fig. 2-d, e).

考察 : 動脈門脈血流の変化をとらえることができる CTHA およびCTAPによる画像診断は, 肝腫㾿の血流 動態診断の golden standard とされ, s CTHA 撮像後期 における腫瘍外周のコロナ様濃染は肝細胞癌の特徵の 一つとされている。 これは, 肝細胞癌から流出する血 液が, 周辺の微小門脈を流出路として圧平衡に達する まで門脈内を逆流したのち本来の還流域を流れるため に, 撮像後期において腫瘍の外周を取り巻くように濃 染が生じる現象であり, 病理学的にも腫瘍外周からの 流出血管が周辺肝の微小門脈枝に連続する像がとらえ られ, 報告されている11. 本稿では, FNH および被膜を 有さない高分化肝細胞癌においてもコロナ様濃染を呈 することを示した. Fukukura らは，FNH の血流が 2 種類の経路, すなわち直接静脈系に還流する系と腫瘤 血洞から周辺肝の類洞に還流する系とを介してドレナー ジされることを病理組織の検討から報告している ${ }^{4}$. 通 常, FNH 症例においては明瞭なコロナ様濃染を指摘さ れていないが, Miyayama らも上記 2 系統のドレナージ 経路について考察し, S CTHA を施行した 3 症例の小 FNH 結節の輪郭が, 撮像後期に不整形から円形に変化 したことが，後者のドレナージ経路による可能性を示 唆するとしている ${ }^{5}$. 本症例では, 細針生検により採取 された組織であるため結節からの流出血管についての 組織学的検討はできないが, コロナ様濃染を呈した理 由の一つとして, 腫瘤径が Miyayama らの症例に比し 

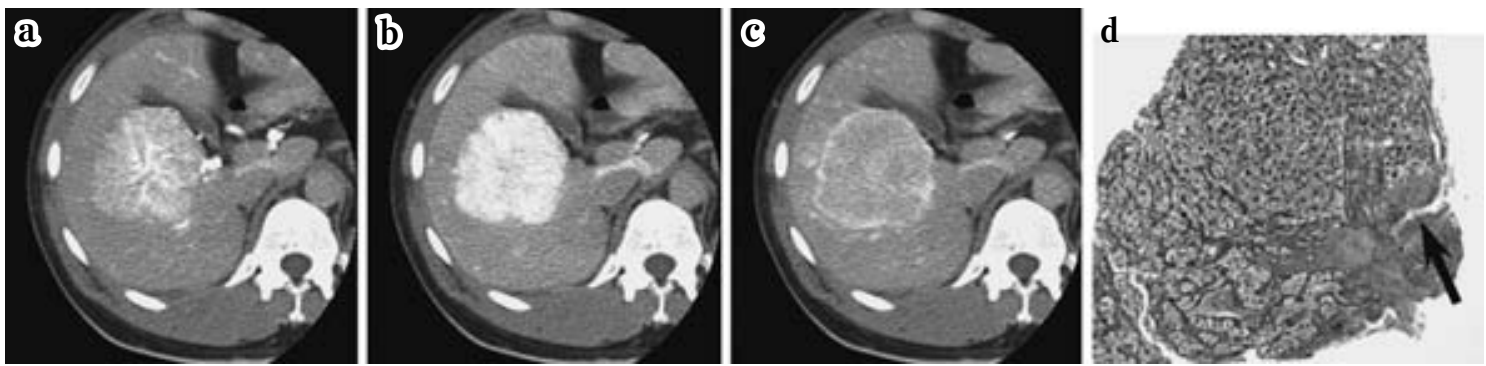

Fig. 1 (a, b, c) Single level dynamic CTHA images of an FNH obtained 3, 8 and 22 seconds after an injection of contrast medium (CM). A spoke-wheel like appearance of the vessels is visible (a), and a thin and rather faint corona enhancement is shown (c). d) Histological examination. The nodule showed neither cellular nor structual atypia, but did show slight liver cell hyperplasia. Inside the nodule were scattered fibrous scars, which contained artery-like vessels (arrow).
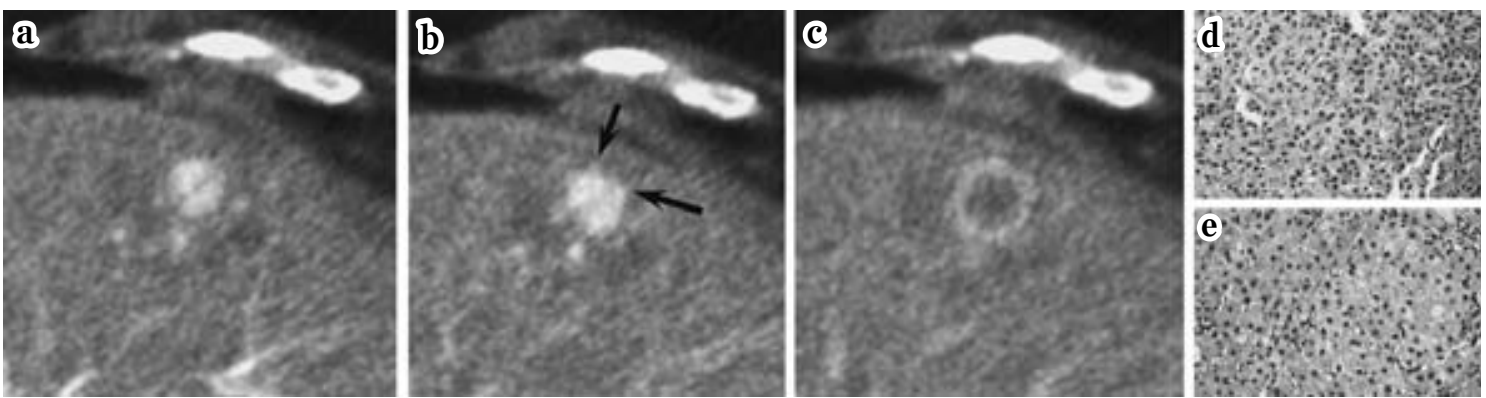

Fig. 2 (a, b, c) Single level dynamic CTHA images of a nodule-in-nodule type HCC obtained 4,6 and 24 seconds after an injection of CM. At 4 seconds, the contour of the tumor is visible (a). At 6 seconds, a vessel-like structure is visible outside the inner tumor (arrow) and the drainage area emerges in an irregular shape (b). At 24 seconds, a corona enhancement is seen just outside of the inner nodule but inside the outer nodule (c). (d,e) Histological examination. A specimen was taken including the border between outer and inner nodules(d). Hepatocytes in the right portion show more increased cellularity and hyperchromatic than those in the left. The former show replacing growth pattern and there seems no capsule-like structure among them. (e) Surrounding liver parenchyma.

$7 \mathrm{~cm}$ と大きいため腫瘤流入および流出血流量も多く,

通常の肝静脈を介する排血路のみならず，腫瘤血洞か ら類洞を介した排血量も増多した可能性を考える。す なわち, FNH では Fukukura らの指摘するように直接 静脈に還流する系と腫瘤血洞から類洞を介する系が存 在するが，通常は主として前者が機能し，後者の血流 量の多い症例でのみコロナ様濃染が顕視化すると考え られる. Drainage vein である周辺肝静脈が圧排され, コロナ様濃染の一部になっている可能性は否定できな いが，腫瘤全周に及ぶ濃染を説明するには不十分と考 える.
肝細胞癌における Ueda らの報告では, コロナ様濃染 出現の早期に門脈枝様の脈管影がリング内に描出され, 濃染像はその存在に一致する楔状を呈することが指摘 されている ${ }^{1)}$. 本稿の結節内結節型肝細胞癌症例では, 多血性腫瘍が $1 \mathrm{~cm}$ と小さいため詳細な検討は困難であ るが，コロナ様濃染出現早期に脈管様とも思われる構 造物が存在した (Fig. 1-b). 結節内結節型肝細胞癌では, 内包される結節の周囲に被膜様の隔壁（偽被膜）の存 在を指摘されることがある，本症例は手術標本ではな いため，その存在を否定することはできないが，針生 検にてとらえられた多血性腫瘍部と外周腫瘍との境界 には通常の被膜は認められていない.したがって、コ ロナ様濃染を呈することに，内包される多血性腫瘍内 の血洞と外周腫瘍の類洞様血液腔を介する系が機能し ていると考えられるが，この時点ですでに門脈枝への 
逆行を認めているかどうかについては, 脈管様構造物 の確認も含め, 今後の詳細な検討を待つ必要がある.

また，我々は過形成結節についてもコロナ様濃染を認 める症例を経験した ${ }^{3)}$. 中島らは, アルコール多飲者に 発症した過形成結節 5 症例の切除標本について報告し ており, 3 症例において明膫な被膜を有したとしている が6), 流出血流が肝細胞癌のごとく被膜内の小門脈枝を 介して流出するのか, 腫瘤内血洞から被膜内および外 周部に連続する別経路が存在するのか，あるいは被膜 をもたない過形成結節にのみ腫瘤内血洞から類洞を介 したコロナ様濃染が認められるのか, など現時点にお いては不明である．転移性肝癌においても多血性のも のについては，腫瘍血洞から周辺肝類洞を介する流出 血流路の存在を指摘されているが2 , 被膜を持たない肝 細胞癌等ではこのような腫瘍血洞から直接類洞を経由 して流出する血流も関与する可能性がある。本稿の検 討は少数例をもとにした推測であるが, 今後, 症例の 蓄積と共に, さらなる知見が得られるものと思われる.

結語：腫瘤辺縁において腫瘤血洞から類洞を介して 流出する血流によりコロナ様濃染を形成する可能性に ついて考察した.

\section{索引用語：コロナ様濃染, FNH, 高分化肝細胞癌}

文献：1）Ueda K, Matsui O, Kawamori Y, et al. Radiology 1998; 206: 161-166 2) Terayama N, Matsui O, Ueda K, et al. J Comput Assist Tomogr 2002; 26: 975一-980 3）西島規浩, 喜多竜一, 川上 尚 人, 他. 肝 臟 $2006 ; 47: 574-581$ 4) Fukukura Y, Nakashima O, Kusaba A, et al. J Hepatol 1998; 29: 470-475 5) Miyayama S, Matsui O, Ueda K, et al. AJR 2000; 174: 1567-1569 6) 中 島 収, 渡辺次郎, 田中将也, 他. 肝臟 1996 ; $37: 704-713$

\section{英文要旨}

Corona enhancement may emerge via sinusoidal drainage pathways

Ryuichi Kita ${ }^{1)}$, Norihiro Nishijima ${ }^{1)}$, Masato Nakatsuji ${ }^{11}$, Hisato Kawakami ${ }^{11}$, Yasuaki Sakamoto $^{11}$, Hiroo Matsuo ${ }^{11}$, Sumio Saito ${ }^{1)}$, Kiyoaki Hatano ${ }^{1)}$, Atsuyuki Ikeda ${ }^{1)}$, Akihiro Nasu ${ }^{1)}$, Hiroki Nishikawa ${ }^{1)}$, Toru Kimura ${ }^{1)}$, Yukio Osaki ${ }^{1 /}$, Osamu Nakashima ${ }^{2)}$

Corona enhancements on single level dynamic CTHA (sCTHA) images are thought to be characteristic of hypervascular metastatic liver tumors and HCCs. Herein we present two cases (an FNH and a nodule-innodule type HCC) in which sCTHA images showed corona enhancements. In the literature, venous and sinusoidal drainage pathways have been confirmed histopathologically in FNH. We presume that drainage flow occurs mainly through a hepatic venous pathway in FNH and that drainage flow via a sinusoidal pathway is faint and may be visible only when the amount of drainage flow becomes large followed by an increase in tumor size. Moreover, a corona enhancement was also seen in a HCC that lacked a capsule but had a replacing growth pattern. A drainage pathway via a sinusoid may be causing the emergence of a corona enhancement on sCTHA images in the cases discussed herein.

Key words: corona enhancement, FNH, well-differentiated HCC

Kanzo 2007; 48: 246-248

1) Department of Gastroenterology and Hepatology, Osaka Red Cross Hospital

2) Department of Pathology, Kurume University School of Medicine

*Corresponding author: rkita@osaka-med.jrc.or.jp 